ISSN 2518-1521 (Online), ISSN 2226-2830 (Print)

ВІСНИК МАРІУПОЛЬСЬКОГО ДЕРЖАВНОГО УНІВЕРСИТЕТУ

СЕРІЯ: ІСТОРІЯ. ПОЛІТОЛОГІЯ, 2020, ВИП. 27

УДК 323.2(497.5-074)

\title{
А. В. Трофименко
}

\section{ДЕОКУПАЦІЯ ТА РЕІНТЕГРАЦІЯ: ДОСВІД ХОРВАТІЇ ДЛЯ УКРАЇНИ}

У роботі представлено аналіз досвіду Хорватії з деокупації та реінтеграції території самопроголоменої Республіки Сербська Краӥна. Досліджено, прочес відновлення територіальної иілісності Хорватії як з допомогою військових наступальних операцій після довготривалих неефективних миротворчих місій ООН, так $і$ иляхом мирного повернення та поступової реінтеграції. Виокремлено фактори, щуо сприяли та перешкоджали изьому процесу, зокрема міжнародне посередництво та допомога, реформування військового сектору, позиція мирного населення, діяльність громадських організацій тощзо. На основі проведеного аналізу встановлено, як досвід Хорватії може бути використаним в украӥнських реаліях.

Ключові слова: деокупачія, реінтеграчія, Республіка Сербська Країна, Східна Славонія, «план Венса», миротворчі місї UNPROFOR, UNCRO, UNTAES, UNPSG.

DOI 10.34079/2226-2830-2020-10-27-142-149

Окупація АР Крим та окремих районів Донецької та Луганської областей внаслідок російської агресії обумовили необхідність пошуку найбільш ефективних інструментів відновлення державного суверенітету на цих територіях. Це обумовлює актуальність дослідження закордонного досвіду з відновлення територіальної цілісності держави, а також реінтеграції повернених територій. Особливо цікавим є досвід тих держав, що повернувши окуповані території, демонструють значні досягнення в розвитку демократії, успішне реформування політичної системи та державного управління, інтенсивний соціальноекономічний розвиток, до яких належить і Хорватія

Проводячи паралелі між війною на південному сході України та іншими територіальними конфліктами все частіше в науковому середовищі звертають увагу на іiі спільні риси з хорватсько-сербським конфліктом 1990-х років, на подібність квазіреспублік «ДНР» та «ЛНР» до самопроголошеної Республіки Сербська Країна, пропонуючи використовувати для деокупації Донбасу саме «хорватський сценарій». Проте, досвід Хорватії з повернення самопроголошеної Республіки Сербська Країн включає два протилежні сценарії, з одного боку, це успішні військові наступальні операції, внаслідок яких більша частина територій була повернена до складу Хорватії, з іншого - це мирна реінтеграції Східної Славонії з допомогою тимчасової адміністрації ООН. Враховуючи зазначене, метою даної роботи є встановлення сутності «хорватського сценарію» деокупації та реінтеграції, виокремлення досвіду Хорватії, що може бути використаним в Україні.

Хорватія була однією 3 перших держав, що заявили про вихід з Соціалістичної Федеративної Республіки Югославії після перемоги в 1990 році на виборах Хорватської демократичної співдружності на чолі з Ф. Туджманом та референдуму в травні 1991 році, де 92 \% населення проголосували за незалежність республіки. 
Проте вихід Хорватії з СФРЮ ускладнювався наявністю великої сербської меншини (12\% населення), яка стала засобом для Сербії в протидії розпаду СФРЮ. Ще до початку військових дій Сербія розпочала інформаційну кампанію, використовуючи дезінформацію про діяльність нової хорватської влади, звинувачуючи ії у фашизмі. Поступово почали з'являтися блокпости в місцях проживання сербського населення, прибувати добровольці 3 Сербіiі [3].

У липні 1991 року відразу після проголошення незалежності сербські військові сили розпочали повномасштабні бойові дії з наступом на схід Хорватії для підтримки сербської меншини. Хорватські збройні сили на той час не могли дати швидкого опору з огляду на слабку підготовку та недостатнє устаткування, крім того на Хорватію розповсюджувалося ембарго на ввезення зброї, накладене РБ ООН на всі колишні республіки СФРЮ у вересні 1991 року. Сербські повстанці змогли зайняти великі райони хорватської території біля кордону з Боснією, і до кінця 1991 року контролювали більше чверті території республіки [5].

19 грудня 1991 року було проголошено про створення Республіки Сербська Країна (РСК) на території центра та сходу Хорватії, що контролювали сербські повстанці за підтримки Югославської народної армії та військових угруповань із Сербії. РСК займала близько 30\% території Хорватії, і в ній мешкали близько 300 тисяч здебільшого етнічних сербів [1]. Сербія на чолі з Президентом С. Мілошевичем забезпечувала значну підтримку РСК, як військову, так і економічну. У 2007 році Міжнародним трибуналом по колишній Югославії (МТКЮ) було доведено, що лідер Республіки Сербська Країна Мілан Мартич мав домовленість з Слободаном Мілошевичем про приєднання РСК до колишньої Союзної Республіки Югославія для створення «єдиної сербської держави».

Через півроку військових дій Європейська спільнота направила своїх спостерігачів у зону конфлікту, 27 серпня 1991 року було створено Миротворчу конференцію з Югославії. На першому етапі конфлікту країни Заходу вбачали можливість припинення військових дій шляхом перетворення СФРЮ на конфедерацію із збереженням існуючих кордонів, Європейська спільнота пропонувала декілька проектів у цьому напрямку. Проте такий сценарій не влаштовував жодну сторону конфлікту. Спроби Свропейської спільноти зупинити військові дії та вирішити кризу в рамках Миротворчої конференції не мали успіху [5].

Крім того, ставлення західних держав до подій в Хорватії зазнало змін після військових дій в м. Дубровнік. Три місяці обстрілів міста з боку Югославської народної армії, що призвели до загибелі мирного населення, вдарили по іміджу Сербії, змусивши світове співтовариство переглянути позицію щодо конфлікту.

Ескалація конфлікту та загибель мирного населення поряд 3 неспроможністю Європейської спільноти зупинити військові дії призвели до активізації зусиль з вирішення конфлікту з боку ООН. Восени 1991 року Генеральний секретар ООН Х.П. де Куельяр направив у Хорватію спецпредставника С. Венса, за посередництвом якого 23 листопада 1991 р. у Женеві було підписано угоду про припинення вогню між Сербією і Хорватією, а 27 листопада 1991 р. Рада Безпеки ООН прийняла Постанову про спрямування до Хорватії миротворчих сил. 2 січня 1992 р. було підписано угоду про безумовне припинення вогню [4].

Запропонований С. Венсом миротворчий план («план Венса»), ухвалений Резолюцією РБ ООН № 724 наприкінці 1991 року, включав такі основні пункти: виведення ЮНА 3 Хорватії, демілітаризацію територій, надання підтримки гуманітарним організаціям, 
ISSN 2518-1521 (Online), ISSN 2226-2830 (Print)

ВІСНИК МАРІУПОЛЬСЬКОГО ДЕРЖАВНОГО УНІВЕРСИТЕТУ

СЕРІЯ: ІСТОРІЯ. ПОЛІТОЛОГІЯ, 2020, ВИП. 27

повернення переміщених осіб в умовах повної безпеки. План передбачав також створення так званих «захисних зон» з боку ООН - UN Protected Areas (UNPA). Це території, «на яких серби становлять більшість або значну меншість населення, де напруга між спільнотами призвела до озброєного конфлікту». Територія під захистом ООН була поділена на чотири сектори (східний, західний, північний та південний) [5]. Крім того, враховуючи, що розміщення сил ООН розтяглося на півроку з грудня 1991 р. до травня 1992 р., кордони «захисних зон» вже не відповідали лінії фронту, виникли так звані «рожеві зони», що виходили за межі юрисдикції ООН та знаходилися під контролем сербських повстанців, найбільша така зона прилягала до південного сектору, більшість населення в ній складали хорвати [4].

Контроль за демілітаризацією на 12 місяців було покладено на Сили ООН із підтримки миру - UNPROFOR (United Nations Protective Forces), діяльність яких призвела до неоднозначних результатів: їм вдалося стримати сторони від відновлення військових дій, проте вони не змогли забезпечити повної демілітаризації та роззброєння сербів. Їм також не вдалося забезпечити ембарго на ввезення зброї до Хорватії, що надходила через Угорщину i Словенію. Ця ситуація призвела до неодноразового подовження мандату UNPROFOR [5].

За роки UNPROFOR (1992 - 1995 pp.) крім номінального виведення військ Югославської народної армії, жоден з інших завдань не було реалізовано, процес витіснення та, у багатьох випадках, вбивства не-сербів на окупованих територіях продовжувався. До середини 1994 року, за оцінками уряду, лише 194 тисяч з 550 тисяч довоєнного населення залишалися проживати в окупованих районах, лише 10 тисяч з них були не сербами. За цих обставин передбачувана нездатність до досягнення політичного рішення виявилася головною перешкодою для реалізації будь-якого аспекту мандату [12]. У східному секторі в період 1992-1993 рр. було вбито 800 та зникло безвісти 1000 хорватів. На підконтрольній хорватам території витіснялися серби. Хорватська армія також в порушення домовленостей провела декілька наступів - «Масленіца» (березень 1993 р.) та «Медак» (вересень 1993 р.), завдяки яким окуповані території було зменшено. РБ ООН реагувала на це резолюціями, які констатували стурбованість зазначеними діями [4].

Неефективність миротворчої операції була очевидною, у тому числі і для ООН. У доповіді 17 вересня 1994 року Генеральний Секретар ООН зазначив, що демілітаризація «захисних зон», встановлення хорватського контролю над «рожевою зоною», встановлення контролю на кордоном, а також сприяння поверненню переміщених осіб залишаються невирішеними питаннями. Таким чином, жоден пункт «плану Венса» втілити не далося. Для зміни ситуації було створено групу у складі двох представників від Міжнародної конференції з колишньої Югославії та послів США і Росії в Хорватії - група 3-4 (Загреб-4), яка запропонувала план мирного врегулювання хорватського «замороженого конфлікту», що передбачав широку автономію для етнічних сербів у Хорватії. РСК мала отримати уряд, президента, валюту та подвійне громадянство. Проте цей план також не влаштував жодну із сторін [1].

У свою чергу, зростала невдоволеність миротворчою місією ООН і у політичних колах Хорватії, 23 вересня 1994 року парламент Хорватії ухвалив резолюцію, що визнала іiі неуспішною, а в січні 1995 року Президент Ф. Туджман оголосив, що мандат UNPROFOR більше не буде подовжуватися після його закінчення 31 березня 1995 року. У відповідь РБ OOH проголосувала за зміну місії UNPROFOR на Операцію OOH з відновлення довіри в Хорватії - UNCRO (UN Confidence Restoration Operation in Croatia), проте завдання майже не змінилися, не зважаючи на вимоги Хорватії. Замість встановлення контролю над 
ISSN 2518-1521 (Online), ISSN 2226-2830 (Print) ВІСНИК МАРІУПОЛЬСЬКОГО ДЕРЖАВНОГО УНІВЕРСИТЕТУ СЕРІЯ: ІСТОРІЯ. ПОЛІТОЛОГІЯ, 2020, ВИП. 27

кордоном, ООН уповноважила UNCRO тільки на «допомогу у контролі, шляхом моніторингу та звітності за перетином військового персоналу, обладнання, запасів i зброї» [5].

Неефективність миротворчих місій ООН спонукала хорватське керівництво до зміни своєї конфліктної стратегії, чому сприяло реформування армії з допомогою Вашингтону. У травні 1995 року хорватські збройні сили провели операцію «Блиск», повернувши контроль над Західною Славонією (10\% окупованих територій), а після зриву нових переговорів у Женеві провела ще одну наступальну операцію «Буря» в серпні 1995 року, повернувши контроль над північним та південним секторами [5].

В наслідок військових операцій край покинуло близько 200 тисяч сербів. Вони разом iз керівництвом самопроголошеного краю залишили Хорватію i стали біженцями здебільшого у сусідній Сербії. Після операції "Буря" було зруйновано тисячі домівок, загинули понад тисяча людей, майже половина з них - цивільні [1].

Під контролем сербів залишився тільки східний сектор (Східна Славонія), що складав 5\% території Хорватії. Зміна балансу сил через посилення військового потенціалу Хорватії, призвела до розуміння сербами Східної Славонії, що у випадку відмови від реінтеграції шляхом дипломатії та переговорів, контроль над територією буде відновлено у військовій формі. Таким чином, для Східної Славонії було розроблено план мирної реінтеграції.

Переговори щодо мирного повернення Східної Славонії розпочалися відразу після операції «Буря», вони стали частиною ініціативи Президента США Б. Клінтона щодо мирного вирішення конфлікту в Боснії та Герцеговині. Перший проект мирної угоди для Східної Славонії було запропоновано хорватському уряду американським послом П. Голбрайтом 2 вересня 1995 року після чого відбулася серія дипломатичних переговорів, головним з яких стала зустріч 1 листопада 1995 року в Дейтоні, коли Президенти Хорватії та Сербії, Ф. Туджман та С.Мілошевич дійшли домовленості. 12 листопада 1995 року було підписано Ердутську угоду про статус Східної Славонії, Барані і Західного Срема представниками Хорватії та місцевою сербською владою цих регіонів у присутності американського посла П. Голбрайта та посередника ООН Т. Столнтенберга [7].

Ердутська угода передбачала закінчення війни і встановлювала перехідний період для інтеграції територій до складу Хорватії. Вона складалася 314 статей, що містили такі основні моменти: встановлення перехідного періоду в 12 місяців з можливістю подовження; звернення до РБ ООН щодо встановлення Перехідної адміністрації для управління регіоном в цей період та розміщення міжнародних сил для підтримання миру та безпеки; демілітаризація протягом максимум 30 днів після розгортання міжнародних сил; забезпечення повернення біженців та переміщених осіб; встановлення тимчасових поліцейських сил; повернення всім особам незалежно від національності власності, відібраної внаслідок незаконних дій, або компенсація за власність, що неможливо повернути; проведення місцевих виборів не пізніше ніж за 30 днів до закінчення перехідного періоду під наглядом міжнародних організацій та зацікавлених країн; повагу до міжнародно визнаних прав людини та фундаментальних свобод [10]. На основі цієї угоди була створена Об'єднана рада муніципалітетів з сербською більшістю населення.

Також угода передбачала набуття чинності після ухвалення відповідної резолюції РБ ООН. 15 січня 1996 РБ ООН ухвалили Резолюцію 1037, що запровадила на 12 місяців операцію з підтримки миру «Тимчасова адміністрація ООН для Східної Славонії, Барані та Західного Срема» - UNTAES (United Nations Transitional Administration for Eastern Slavonia, Baranja and Western Sirmium), до складу якої входили як військовий, так і цивільний 
ISSN 2518-1521 (Online), ISSN 2226-2830 (Print)

ВІСНИК МАРІУПОЛЬСЬКОГО ДЕРЖАВНОГО УНІВЕРСИТЕТУ

СЕРІЯ: ІСТОРІЯ. ПОЛІТОЛОГІЯ, 2020, ВИП. 27

компоненти. На початковому етапі операція мала складати 5 тисяч військовослужбовців, мандат яких включав нагляд за демілітаризацією, безпечним поверненням біженців та переміщених осіб, сприяння своєю приступністю підтримці миру та безпеки. До обов'язків цивільного компоненту UNTAES входило створення тимчасових поліцейських сил, організація виборів, координація планів розвитку та відновлення економіки цього району тощо [11]. Двома днями пізніше ухвалення Резолюції Генеральний секретар ООН призначив керівника місії, яким став генерал США, дипломат Ж.П. Кляйн, що користувався значною повагою як серед хорватів, так і серед сербів, важливість цього факту збільшувалася в атмосфері повної недовіри сторін на початку реінтеграції.

Найбільш важливе завдання місії $\mathrm{OOH}$ - демілітаризація - була завершена в червні 1996 року, до Сербії повернулися іiї військові сили, чотири бригадні корпуси, 118 танків, 19 броньованих машин, 150 мінометів та інше озброєння. Складним був процес створення змішаних хорватсько-сербських поліцейських сил через повну недовіру та ворожість між етносами. Проте, не дивлячись на це, слід підкреслити, що протягом дворічного процесу мирної реінтеграції не мало місце жодного критичного інциденту між сторонами. Цьому сприяла діяльність неурядового сектору, хорватських та сербських НУО, діяльність яких підтримувалася з боку керівництва UNTAES. Крім того, наступного дня після завершення демілітаризації 23 червня 1996 року за ініціативою генерала Кляйна було назначено місце зустрічі представників комерційного сектору біля Осієку, що отримало назву «ринок Кляйна». Протягом трьох місяців до вересня 1996 року його відвідало більше 60 тисяч осіб 3 двох сторін колишнього кордону, що стало значним кроком у відновленні довіри [7].

Іншим важливим та чуттєвим моментом реінтеграції стало повернення біженців та переміщених хорватів та сербів у їх довоєнні домівки. Закон про загальну амністію 17 травня 1996 року частково заспокоїв побоювання сербів щодо переслідувань за воєнні злочини (хоча питання воєнних злочинів досі залишається невирішеною проблемою), і у листопаді 1996 року почали повертатися перші переміщені особи в селища так званого Сермійського трикутника - південного району, що першим було передано Хорваті під час UNTAES. Надалі все більше територій було відкрито для повернення [7].

UNTAES вже відбувалася в іншому більш сприятливому політичному середовищі порівняно з попередницями. Її завданням стало досягнення «... мирної реінтеграції регіону в конституційну систему Хорватії шляхом реалізації базової угоди». Поступово в рамках операції скорочувався контингент ООН та розширювалися функції Перехідних поліцейських сил, 40\% з яких припадало на хорват, $40 \%$ - на сербів та $20 \%$ - на представників інших етнічних груп. Пізніше ці сили перейшли під контроль Міністерства внутрішніх справ Хорватії [8].

Завершило процес реінтеграції проведення місцевих виборів 13 квітня 1997 року, які також відбулися без серйозних інцидентів. 15 червня 199 року Вуковар відвідав Президент Ф. Туджман на так званому «потязі миру», він виступив 3 промовою, запропонувавши сербам мирне життя в Хорватії [7].

У 1998 році UNTAES завершилася передачею уряду контролю над регіоном. 16 січня 1998 року поліцейські функції від UNTAES були передані Групі підтримки цивільної поліції OOH - UNPSG (United Nations Police Support Group), що налічувала 180 осіб. Її функція полягала в продовженні моніторингу діяльності хорватської поліції в Дунайському регіоні, зокрема щодо повернення переміщених осіб. 27 жовтня 1998 року Генеральний секретар заявив, що мандат Групи повністю завершений і закінчився 15 жовтня 1998 року. Обов'язки 
ISSN 2518-1521 (Online), ISSN 2226-2830 (Print) ВІСНИК МАРІУПОЛЬСЬКОГО ДЕРЖАВНОГО УНІВЕРСИТЕТУ СЕРІЯ: ІСТОРІЯ. ПОЛІТОЛОГІЯ, 2020, ВИП. 27

поліцейського моніторингу наступного дня взяла на себе Організація 3 безпеки та співробітництва в Свропі (ОБСЕ) [12].

15 січня 1998 року Східна Славонія, Бараня і Західний Срем були остаточно включені до складу Хорватії.

Таким чином, зусилля міжнародної спільноти з врегулювання хорватсько-сербського конфлікту та врегулювання статусу РСК виявилися неефективними. Пасивність міжнародних організацій на ранніх етапів конфлікту, завишенні очікування та завдання миротворчих місій ООН обумовили неспроможність зупинити ескалацію конфлікту та гибель мирного населення. Посилення військового потенціалу Хорватії, що відбулося за часи місій UNPROFOR та UNCRO, дозволило державі змінити конфліктну стратегію та провести дві успішні наступальні операції, в наслідок яких більша частина територій була де окупована. Проведенні військові операції хорватською армією, що забезпечили швидке відновлення контролю над більшою частиною самопроголошеної Республіки Сербська Країна, забезпечили Хорватії можливість повернути контроль над останнім регіоном мирним шляхом на власних умовах. Хорватія провела переговори 3 представниками сербської влади, гарантувала сербським формуванням амністію, в квітні 1997 року проведено місцеві вибори, для участі в яких населення регіону мало отримати громадянство Хорватії. Протягом дворічного процесу реінтеграції завдяки ефективному посередництву $\mathrm{OOH}$, прагненню населення обох етнічних спільнот до встановленню миру було забезпечено повну демілітаризацію, безпечне повернення переміщених осіб. У результаті, територія Східної Славонії була повністю інтегрована до Хорватії без розширення її статусу.

Досвід Хорватії з відновлення територіальної цілісності демонструє неефективність покладання держави тільки на допомогу міжнародного співтовариства, необхідність розробки власної національної стратегії з урахуванням всіх аспектів конфлікту, що забезпечить безпеку мирного населення та об'єктів інфраструктури, а також свідчить про безумовні переваги стратегії мирної реінтеграції окупованих територій під контролем миротворчих місій, що може бути використана як основа деокупації ОРДЛО в Україні.

Не дивлячись на відмінності між хорватсько-сербським конфліктом та російськоукраїнською війною, зокрема в питанні наявності в регіоні конфлікту національної меншини, досвід Хорватії з мирної реінтеграції може бути, хоч і частково, використаним в українських реаліях. Повномасштабне його використання наразі не є можливим, з огляду на позицію України не вести жодних переговорів з представниками окупаційних адміністрацій так званих ДНР та ЛНР, крім того обгрунтоване визнання Росії країною-агресором на законодавчому рівні також унеможливлює присутність російських миротворців в зоні конфлікту. Малоймовірним вбачається і ухвалення резолюції РБ ООН щодо впровадження операції $з$ підтримки миру з огляду на постійне членство та право вето РФ в цій інституції. Тим не менш, досвід Хорватії в частині миробудівництва, відновлення довіри між населенням двох сторін лінії розмежування, повернення переміщених осіб, визнання цивільно-правових документів, виданих на непідконтрольних територіях, питання пенсій, введення перехідних поліцейських сил, міжнародне посередництво та допомога в процесі реінтеграції населення зони конфлікту в мирне громадське життя держави може допомогти при розробці більш ефективної стратегії щодо реінтеграції тимчасово окупованих територій Донецької та Луганської областей. 
ISSN 2518-1521 (Online), ISSN 2226-2830 (Print)

ВІСНИК МАРІУПОЛЬСЬКОГО ДЕРЖАВНОГО УНІВЕРСИТЕТУ

СЕРІЯ: ІСТОРІЯ. ПОЛІТОЛОГІЯ, 2020, ВИП. 27

\section{Список використаної літератури}

1. Варга Б. Річниця операції "Буря": як Хорватія поборола сепаратизм [Електронний ресурс] / Б. Варга // ВВС Україна. - 2015. - 4 серпня. - Режим доступу : https://www.bbc.com/ukrainian/politics/2015/08/150803_croatia_military_operation_a nno_hk ; Varga B. Richnytsia operatsii "Buria": yak Khorvatiia poborola separatyzm [Elektronnyi resurs] / B. Varga // VVS Ukraina. - 2015. - 4 serpnia. Rezhym dostupu : https://www.bbc.com/ukrainian/politics/2015/08/150803_croatia_military_ope ration_anno_hk

2. Казанський Д. Хорватія. 20 років на примирення [Електронний ресурс] / Д. Казанський // Тиждень. - 2016. - 26 березня. - Режим доступу : https://tyzhden.ua/World/161579; Kazanskyi D. Khorvatiia. 20 rokiv na prymyrennia [Elektronnyi resurs] / D. Kazanskyi // Tyzhden. - 2016. - 26 bereznia. - Rezhym dostupu : https://tyzhden.ua/World/161579

3. Левченко О. Чому Хорватії вдалося: як країна повернула території після років окупації та гібридної війни [Електронний ресурс] / О. Левченко // Європейська правда. 2017. $\quad$ - 4 серпня. 4 - Режим доступу

https://www.eurointegration.com.ua/articles/2017/08/4/7069423 ; Levchenko O. Chomu Khorvatii vdalosia: yak kraina povernula terytorii pislia rokiv okupatsii ta hibrydnoi viiny [Elektronnyi resurs] / O. Levchenko // Yevropeiska pravda. - 2017. - 4 serpnia. - Rezhym dostupu : https://www.eurointegration.com.ua/articles/2017/08/4/7069423

4. Нагірний М. 3. Миротворчі зусилля світової спільноти у хорватсько-сербській війні 1990-х рр. і сучасний український контекст [Електронний ресурс] / М. 3. Нагірний // Грані. - 2015. - № 6 - C. 180-185. - Режим доступу : http://dspace.tneu.edu.ua/bitstream/316497/2025/1/Grani_2015_6_35.pdf ; Nahirnyi M. Z. Myrotvorchi zusyllia svitovoi spilnoty u khorvatsko-serbskii viini 1990-kh rr. i suchasnyi ukrainskyi kontekst [Elektronnyi resurs] / M. Z. Nahirnyi // Hrani. - 2015. - № 6 - S. 180-185. Rezhym dostupu : : http://dspace.tneu.edu.ua/bitstream/316497/2025/1/Grani_2015_6_35.pdf

5. Krsticevic D. United Nations Protection Force (UNPROFOR) in Croatia. [Electronic resource] / D. Krsticevic. - Mode of access : https://apps.dtic.mil/dtic/tr/fulltext/u2/a345006.pdf

6. Lachowski T. Transitional Justice in Ongoing Conflicts and Post-War Reconstruction: Reintegrating Donbas into Ukraine [Electronic resource] / T. Lachowski // Polish Political Science Yearbook. - 2017. - Vol. 46, Issue 2. - P. 36-54. - Mode of access : https://www.researchgate.net/publication/322086404_Transitional_Justice_in_Ongoing_Conflict s_and_Post-War_Reconstruction_Reintegrating_Donbas_into_Ukraine

7. Pavelić B. Peaceful Reintegration. The Discarded Triumph of Reason and Peace [Electronic resource] / B. Pavelić // Friedrich Ebert Stiftung. - Zagreb, 2018. - Mode of access : https://library.fes.de/pdf-files/bueros/kroatien/14483.pdf

8. Simonovic I. UNTAES: a Case Study [Electronic resource] / I. Simonovic, I. Nimac // Croatian International Relations Review. - 1999. - Vol. 5, №. 14. - P. 5-10. - Mode of access : https://pdfs.semanticscholar.org/90d8/cdd98c5dce5ab0f10144add444327c5d4657.pdf

9. Skare-Ozbolt V. Peaceful Reintegration of Eastern Slavonia, Baranja and Western Sirmium [Electronic resource] / V. Skare-Ozbolt // Croatia, the war, and the future. Ina Vukic Croatia: people, politics, history, economy, transition from communism to democracyurl. - 2013. 
ISSN 2518-1521 (Online), ISSN 2226-2830 (Print) ВІСНИК МАРІУПОЛЬСЬКОГО ДЕРЖАВНОГО УНІВЕРСИТЕТУ СЕРІЯ: ІСТОРІЯ. ПОЛІТОЛОГІЯ, 2020, ВИП. 27

- January 19. - Mode of access : https://inavukic.com/2013/01/19/croatia-open-sesame-peacefulreintegration-of-eastern-slavonia

10. The Erdut Agreement. November 12, 1995 [Electronic resource] // United States Institute of Peace. Peace Agreements Digital Collection. - Mode of access : https://inavukic.files.wordpress.com/2013/01/croatia_erdut_11121995.pdf

11. UN Resolution 1037 (1996). Adopted by the Security Council at its 3619th meeting, on 15 January 1996 [Electronic resource] // United Nations Security Council. S/RES/1037. - 1996. 15 January. - Mode of access : https://undocs.org/S/RES/1037(1996)

12. United Nations Civilian Police Support Group (UNPSG) Mission Profile [Electronic resource]. - Mode of access : https://peacekeeping.un.org/sites/default/files/past/cropol.htm

Стаття надійшла до редакції 17.12.2019 р.

\section{A. Trofymenko}

\section{DE-OCCUPATION AND REINTEGRATION: EXPERIENCE OF CROATIA FOR UKRAINE}

The occupation of the Autonomous Republic of Crimea and certain districts of Donetsk and Luhansk regions as a result of Russian aggression cause the relevance of the study of foreign experience in restoring the territorial integrity of the country and the reintegration of the returned territories.

The article presents an analysis of experience of Croatia in the de-occupation and reintegration of the territory of the self-proclaimed Republic of Serbian Krajina. The process of restoring the territorial integrity of Croatia through the military offensive operations after longterm ineffective peacekeeping missions of UN as well as through a peaceful return and gradual reintegration under the control of international peacekeeping missions has been researched. The factors contributed to and hindered this process, in particular, international mediation and assistance, reformation of the military sector, the position of non-combatants, the activity of public organizations and etc. were outlined.

Based on the conducted analysis, it has been established that experience of Croatia in peaceful reintegration can be used in Ukraine in the field of peacebuilding, restoration of trust between the population of two sides of delimitation line, the return of displaced people, recognition of civil law documents issued at uncontrolled territories, pension issues, introduction of transitional police forces, international mediation and assistance in the process of reintegration of the population of the conflict zone into the peaceful public life of the country can help to develop more effective strategies as for the reintegration of the temporarily occupied territories of Donetsk and Luhansk regions.

Key words: de-occupation, reintegration, The Republic of Serbian Krajina, Eastern Slavonia, Wance plan, peacekeeping missions UNPROFOR, UNCRO, UNTAES, UNPSG. 